\title{
Analisis Hubungan Kerja Sama Bilateral Australia dan Fiji dalam Bidang Keamanan pada Periode 2014-2019
}

\author{
Siti Dhea Meutia Syarif \\ Universitas Islam Negeri Syarif Hidayatullah Jakarta
}

\begin{abstract}
ABSTRAK
Penelitian ini menganalisis hubungan kerja sama bilateral Australia dan Fiji dalam bidang keamanan periode 2014-2019. Memasuki era demokratisasi pasca-Kudeta Fiji Tahun 2006, hubungan antara Canberra dan Suva terlihat semakin membaik. Sejumlah inisiasi keamanan regional dan bahkan internasional terlihat digalakan. Atas latarbelakang ini, tulisan ini berargumen bahwa konvergensi kepentingan antara keduanya dapat diatribusikan pada adanya kesamaan persepsi dalam hal pertahanan regional dan internasional yang semakin prominen di era demokratisasi Fiji. Untuk membuktikan hal tersebut, tulisan ini dimulai dengan menjabarkan metodologi dan kerangka teoritis analisis kebijakan luar negeri yang digunakan untuk menganalisis fenomena tersebut. Bagian berikutnya akan memaparkan latar belakang dari hubungan kontemporer antara Australia dan Fiji dan menganalisis bagaimana dinamikanya dapat berujung pada kolaborasi yang dimaksud. Tulisan ini diakhiri dengan menganalisis prospek dari ketahanan hubungan bilateral kedua negara ini di masa mendatang dengan adanya ploriferasi tantangan-tantangan keamanan baru.
\end{abstract}

Kata-kata Kunci: Hubungan Bilateral, Keamanan, Kepentingan Nasional, Australia, Fïji

This study analyzes Australia and Fiji's bilateral cooperation in the security sector for the 2014-2019 period. Entering the democratization era after the Fiji Coup in 2006, the relationship between Canberra and Suva seems to be getting better. Several regional and even international security initiatives were seen as being encouraged. This paper then argues that the convergence of interests between the two can be attributed to the similarity of perceptions in terms of regional and international defense, which is increasingly prevalent in the era of democratization in Fiji. This paper begins by describing the methodology and theoretical framework of foreign policy analysis used to analyze this phenomenon. The next section provides background on contemporary relations between Australia and Fiji and analyzes how their dynamics led to the collaboration in question. This paper ends by analyzing the prospects for the resilience of bilateral relations between the two countries in the future with the proliferation of new security challenges.

Keywords: Bilateral Relations, Security, National Interest, Australia, Fiji 
Australia dan Fiji merupakan dua negara yang memiliki keinginan yang sama untuk terlibat dalam bidang keamanan, terutama dalam stabilitas internasional. Sebagaimana yang dituliskan oleh Andrew Carr (2014), posisi Australia sebagai middle-power-dengan semakin intensifnya upaya asersi pengaruh melalui multilateralisme di area Asia-Pasifik dan sejumlah aliansi stratejik, umumnya dengan Amerika Serikat-kini tengah berada di suatu persimpangan. Ancaman keamanan bagi Australia yang seakan-akan terisolir dari dunia luar semakin terploriferasi, seperti fenomena rising dari Tiongkok yang membuat haluan pertahannya semakin bercondong ke arah Washington. Begitu pula dengan Fiji. Meskipun memiliki kedudukan dan kapabilitas yang relatif berbeda, Tarte (2010) melihat negara ini memiliki persepsi keamanan yang serupa dalam konteks regional dengan fokusnya pada aspek pertahanan. Terlebih lagi, kerja sama keamanan yang semakin erat antar kedua negara tersebut-utamanya pada era demokratisasi Fiji tahun 2014 (McDougall 2017)-mengesankan suatu pergeseran pola dinamika tersendiri yang patut untuk dikaji.

Hubungan antar kedua negara tersebut tidak selalu berjalan demikian. Semenjak terjadinya kudeta pada tahun 2006 silam, Fiji menjadi negara yang terasing dari kawasan Pasifik. Kondisi ini lantas membuat negara ini menempuh jalur relasi ekstra-regional, berfokus pada pertumbuhan kapabilitas ekonomi, dan mempromosikan relasi sub-regional. Menurut Lawson (2015), salah satu contoh dari ketegangan ini adalah penangguhan Fiji dari organisasi regional di Pasifik, serta pelarangan Fiji untuk terlibat dalam operasi perdamaian Perserikatan Bangsa-bangsa (PBB). Hal ini lantas turut meningkatkan perselisihan antara Fiji dengan Australia dan Selandia Baru karena dianggap telah membujuk negara-negara kepulauan Pasifik lainnya untuk mendukung langkah tersebut. Pada awalnya, Fiji sengaja tidak memprioritaskan Australia dalam lingkup relasi baik secara bilateral maupun regional. Hal tersebut dilakukan mengingat dominasi Australia di kawasan tersebut dan ambisi Suva untuk mengurangi ketergantungannya pada Canberra. Misalnya, Fiji telah menandatangani nota kesepahaman dalam bidang militer dengan Brazil, Cina, Rusia, Uni Emirat Arab, dan Israel karena penangguhan kerja sama pertahanan dengan Australia. (Cramer 2015).

Tensi pun berubah ketika Canberra memutuskan untuk membangun kembali hubungan kerja sama pertahanan dengan Suva setelah pemilihan umum digelar kembali delapan tahun semenjak kudeta terakhir melanda negara ini. Intensi baik ini salah satunya ditunjukan oleh Australia dengan adanya pertukaran intelijen 
antara Australia dan Fiji terkait upaya penjaminan pembebasan 44 warga Fiji yang tertangkap di Dataran Tinggi Golan (Global Security 2020) - tepat menjelang pemilihan umum hendak diselenggarakan. Hubungan Bilateral pun kembali ternormalisasi secara perlahanlahan. Dalam ranah keamanan dan perdamaian, Australia pun semakin meningkatkan dukungan terhadap Fiji, utamanya manifestasi keeratan hubungan tersebut melalui Kemitraan Vuvale Fiji-Australia.

Melihat adanya perubahan iklim relasi antar kedua negara ini, tulisan ini hendak menelusuri bagaimana dinamika hubungan bilateral Austalia dan Fiji yang penuh dengan ketegangan-utamanya pasca-kudeta tahun 2006-dapat berakhir pada suatu kooperasi dan kolaborasi, utamanya dalam konteks keamanan. Tulisan ini hendak mengargumentasikan bahwa konvergensi kepentingan ini dapat diatribusikan pada adanya kesamaan persepsi dalam hal pertahanan regional dan internasional yang semakin prominen di era demokratisasi Fiji. Untuk membuktikan hal tersebut, tulisan ini akan dimulai dengan menjabarkan metodologi dan kerangka teoritis analisis kebijakan luar negeri yang akan digunakan untuk menganalisis fenomena ini. Bagian berikutnya akan memaparkan bagaimana latar belakang dari hubungan bilateral Australia dan Fiji kontemporer dan menganalisis bagaimana dinamikanya dapat berujung pada kolaborasi yang dimaksud. Tulisan ini akan diakhiri dengan menganalisis prospek dari ketahanan hubungan bilateral kedua negara ini di masa mendatang dengan adanya ploriferasi tantangan-tantangan keamanan baru.

\section{Meletakan Posisi Hubungan Fiji-Australia dalam Kerangka Analisis Kualitatif Kebijakan Luar Negeri}

Dalam menganalisis rumusan masalah yang telah diambil, fenomena hubungan bilateral Australia dan Fiji akan ditangkap dalam koridor kajian kualitatif. Penelitian kualitatif adalah penelitian yang bertujuan untuk memahami fenomena sosial tentang apa yang dialami oleh subjek penelitian, seperti perilaku, persepsi, motivasi, dan tindakan yang dijelaskan secara deskriptif menggunakan katakata dan bahasa dengan memanfaatkan berbagai metode saintifik (Moleong 2000). Penelitian inibersifat deskriptifkarena menjelaskan mengapa fenomena tersebut bisa terjadi dan mengidentifikasi mengapa hal tersebut bisa terjadi dengan cara mengintepretasikan informasi yang ada secara mendalam. Data yang digunakan dalam literatur ini adalah data-data sekuder yang diperoleh melalui studi literatur. Studi literatur merupakan penelitian yang dilakukan oleh peneliti dengan mengumpulkan sejumlah informasi dari buku-buku 
akademik, jurnal, website yang berkaitan dengan permasalahan dan tujuan penelitian sebagai bahan rujukan, memperoleh data teoritis, serta mendukung kebenaran data penelitian (Danial \& Warsiah 2009).

Dalam menganalisis hubungan kerja sama bilateral Australia dan Fiji dalam Bidang Keamanan Periode 2014-2019, kajian kualitatif yang dimaksud akan diletakan dalam koridor kerangka analisis kebijakan luar negeri dengan penekanan lebih pada konsep kepentingan nasional. Merujuk pada definisi yang dipaparkan oleh James Rosenau, kebijakan luar negeri adalah setidaknya semua kebijakan yang memiliki dampak terhadap relasi antara pemerintah suatu negara dengan pemerintah negara yang lainnya (Rosenau 1961). Modelski (1962) juga menambahkan bahwa kebijakan luar negeri memiliki peranan sebagai suatu sistem yang dibangun oleh negara untuk mengubah perilaku negara lain serta menyesuaikan kegiatan mereka sendiri dengan apa yang terjadi pada lingkungan internasional. Perilaku suatu negara dapat memiliki dampak baik maupun buruk terhadap negara lain. Lantas, meminimalisasi tindakan yang merugikan dan memaksimalkan tindakan yang menguntungkan dari negara asing adalah poin utama dari kebijakan luar negeri. Dengan demikian, kebijakan luar negeri pada dasarnya adalah cara bagaimana suatu negara merespon dan juga membentuk perilaku dari negara lain.

Selain itu, kerangka analisis ini juga diorientasikan untuk memberikan penjelasan dalam kompleksitas pengambilan kebijakan luar negeri yang dapat dianalogikan layaknya memecahkan suatu teka-teki. Kerangka ini juga dirujuk oleh penulis dikarenakan kebijakan luar negeri yang diambil oleh suatu negara memiliki maksud-maksud tertentu yang diorientasikan kepada kepentingan nasional dari negara yang dimaksud. Menggaungkan definisi Joseph Nye (1999), kepentingan nasional merupakan serangkaian prioritas dan orientasi dari suatu negara terhadap tindakan yang akan dilakukan negara tersebut dalam berinteraksi dengan negaranegara lain. Kepentingan tersebut dapat berupa hal-hal yang dinilai signifikan bagi kondisi internal negara tersebut; seperti hak asasi manusia, militer, ekonomi, dan lain sebagainya. Atas dasar hal itu, kepentingan nasional menentukan tindakan politik suatu negara. Tidak ada standar baku yang dapat menentukan apakah suatu aspek spesifik dapat dimaknai sebagai kepentingan nasional. Hal ini dikarenakan setiap negara memiliki bias dan kepentingan nasionalnya masing-masing. Dengan menginkoperasikan konsepsi kepentingan nasional, lantas, menggaungkan penjelasan Holsti, (1990), analisis kebijakan luar negeri dapat mengambil sudut 
pandang yang berkaitan dengan penyelesaian masalah yang dihadapi, serta mencakup elemen-elemen yang berorientasi dalam dicapainya suatu tujuan negara. Berbicara tentang tujuan dan kepentingan dari suatu negara, istilah-istilah seperti perdamaian, keamanan, kekuasaan dan kemakmuran-yang mana merupakan tujuan jangka panjang dalam dikotomi tujuan jangka panjang dan jangka pendek Rosenau (1961) akan cukup sering ditemui dalam analisis ini.

\section{Bilateralisme sebagai Model Kerja Sama Keamanan Australia dan Fiji}

Dalam menjelaskan hubungan bilateral antara Australia dengan Fiji, maka konteksnya tidak akan terlepas dari kata kerja sama bilateral. Sebagaimana hubungan kerja sama pada umumnya, kerja sama bilateral didorong oleh adanya kesamaan kepentingan. Hal ini dapat dilakukan dengan sejumlah pola kerja sama-bergantung pada aktor apa saja yang terlibat-di antaranya, negara dengan negara, negara dengan organisasi pemerintah, maupun negara dengan organisasi non-pemerintah. Merujuk pada Kusumohamidjojo, hubungan bilateral dapat didefinisikan sebagai:

"Suatu bentuk kerja sama di antara negara baik yang berdekatan secara geografis ataupun jauh di sebrang lautan dengan sasaran utamamenciptakanperdamaiandenganmemperhatikankesamaan politik, kebudayaan, dan struktur ekonomi" (Kusumohamidjojo 1987).

Dinamika dari suatu hubungan bilateral dapat dilihat dari kondisi diplomatik yang terjalin antar kedua negara. Dalam konteks Australia dan Fiji, meskipun mengalami pasang surut, hubungan antara kedua negara tersebut telah berlangsung cukup lama. Karena itu, dinamika yang terjadi di antara kedua negara tersebut dapat memiliki keterkaitan tersendiri-baik secara langsung maupun tidak langsung

Didi Krisna (1993) juga menambahkan bahwa-dari segi orientasi dan hasil yang ini dicapai-hubungan bilateral merupakan keadaan yang menggambarkan adanya hubungan yang saling memengaruhi atau adanya hubungan timbal balik di antara kedua belah pihak atau di dalam kedua negara. Jika hasil positif lebih didominasi dalam prosesnya, maka akan terjadi tindakan yang saling ketergantungan/ interdependensi yang akan mengakibatkan kerja sama berlangsung dalam kurun waktu yang lama (Krisna 1993). Hubungan antara Fiji dan Australia telah terjalin cukup lama, maka secara tidak langsung terjadi suatu dinamika yang memiliki keterkaitan antara kedua 
negara akibat adanya kepentingan nasional dari masing-masing pihak. Seperti halnya dalam kerja sama yang terjalin cukup lama dapat memudahkan kedua belah pihak untuk memulai kerja sama di bidang yang lain.

Hal tersebut selaras dengan konsep kepentingan nasional oleh Hans J. Morgenthau, dalam tulisannya ia mengatakan bahwa:

"Kemampuan minimum negara-negara untuk melindungi dan mempertahankan identitas fisik, politik, dan kultural dari gangguan negara-negara lain. Dari tinjauan itu, para pemimpin suatu negara dapat menurunkan suatu kebijakan spesifik terhadap negara lain bersifat kerja sama maupun konflik" (Morgenthau 2005).

Kepentingan nasional sebuah negara sangat bergantung pada tradisi politik dan tradisi kulturalnya. Tradisi politik dapat berarti sistem pemerintahan yang dimiliki, negara-negara yang menjadi partner dalam hubungan diplomatik, hingga sejarah yang menjadikan negara tersebut menjadi seperti saat ini. Tradisi dalam konteks kultural dapat dilihat dari cara pandang dan karakter negara-bangsa yang dimaksud, sehingga menghasilkan kebiasaan-kebiasaan yang dapat menjadi tolak ukur negara sebelum memutuskan menjalankan kerja sama (Morgenthau 2005).

\section{Ketegangan Hubungan Bilateral Australia dan Fiji Pasca- Kudeta 2006}

Fiji telah mengalami kudeta sebanyak empat kali, yakni pada 1987, 2000, 2002, dan 2006. Tiga di antaranya merupakan akibat konflik etnis antara Etnis Fiji asli (Melanesia) yang beragama Kristen Methodis dengan Etnis India yang beragama Hindu (BBC 2006). Dalam kudeta Fiji keempat, pada 5 Desember 2006, terjadi kudeta militer di mana Pasukan Militer Republik Fiji (RFMF) menggulingkan pemerintahan konstitusional Laisenia Qarase, yang telah memenangkan pemilihan demokratis kedua hanya tujuh bulan sebelumnya. Kudeta tersebut juga dinilai banyak melanggar nilai-nillai demokrasi. Sebagai implikasi dari peristiwa ini, terdapat diskriminasi terhadap Etnis India. Kelompok identitas ini tidak diperkenankan untuk menjabat di posisi-posisi vital, seperti kursi perdana Menteri. Meskipun tetap terrepresentasikan di parlemen, namun kedudukan Etnis India mendapat sejumlah pembatasan. Selain itu, kudeta militer tersebut juga dilakukan sebagai upaya lembaga milter Fiji yang berusaha mengambil alih pemerintahan dan menjalankan pemerintahan di bawah aturan militer yang dipimpin oleh Frank Bainimarama (BBC 2006). 
Sebagai negara yang relatif bertetangga dan dalam region yang sama, peristiwa tersebut lantas masuk dalam salah satu konsiderasi lingkar konsentris pemilihan kebijakan luar negeri Australia-mengingat pula bahwa wilayah Pasifik terdiri atas beberapa negara-negara yang rawan terhadap gejolak dan instabilitas politik, seperti kudeta. Pada awalnya, Australia memperluas program bantuannya dan memulai keterlibatan militer yang lebih pro-aktif di Pasifik Selatan dengan tujuan untuk mencapai kemajuan dalam membangun kawasan Melanesia yang lebih stabil, terutama pada negara yang rawan konflik-sebagaimana Fiji. Selain itu, upaya pemerintah Australia dalam merekatkan hubungan dengan Fiji dilakukan untuk menghindari terjadinya efek negatif yang dikhawatirkan akan berpengaruh terhadap negara-negara Pasifik Selatan lainnyaseperti runtuhnya rezim yang demokratis. Tidak hanya itu, Australia juga telah banyak memberikan bantuan pertahanan kepada Fiji karena Australia juga menginginkan peningkatan stabilitas keamanan di kawasan tersebut (Carr 2014).

Sebelumnya, Australia juga telah bekerja dengan negara-negara Pasifik dalam menyusun komitmen regional terhadap demokrasi dalam bentuk Deklarasi Biketawa, di mana negara-negara tersebut-termasuk Fiji-berkomitmen pada tata pemerintahan yang baik, kebebasan dari individu di bawah hukum dan persamaan hak untuk semua warga negara. Komitmen ini disusun bertepatan dengan terjadinya kudeta di Fiji pada era sebelumnya dan sejumlah kekerasan etnis di Kepulauan Solomon. Deklarasi Biketawa merupakan implementasi kerangka kerja samakerja sama pertama yang menetapkan serangkaian prosedur yang harus diambil oleh kawasan pasifik jika terjadi krisis politik di negara anggota, tetapi lingkupnya terbatas sebagai mekanisme keamanan regional. Termasuk dalam hal ini adalah kerja samakerja sama peacekeeping regional dengan kolaborasi antar lembaga kepolisian dan militer tiap negara. (McDonald 2008)

Mengingat pentingnya nilai strategis Fiji, Australia pun melontarkan reaksi resmi atas perubahan status-quo yang terjadi. Hal ini dimanifestasikan dalam berbagai macam bentuk kecaman politik, pengenaan sanksi, dan imbauan, serta seruan kepada warga Fiji untuk menentang pemerintah militer. Perubahan rezim politik ini membuat Australia mulai mempertimbangkan hubungan bilateral dengan Fiji-umumnya di ranah keamanan. Semenjak adanya gejolak ini, Australia mempersepsikan Fiji sebagai ancaman yang dianggap berpotensi membahayakan keamanan nasionalnya sendiri, sehingga Australia memprakarsai keterlibatan yang semakin intensif dengan kawasan Melanesia tersebut (Herr 2010). 


\section{Perubahan Persepsi: Kooperasi Keamanan Australia dan Fiji 2014-2019}

\section{Normalisasi Hubungan Bilateral dan Intensifikasi Keamanan Regional}

Memasuki era yang lebih demokratis di Fiji, hubungan bilateral antar kedua negara semakin baik. Perbaikan ini salah satunya diawali dengan kunjungan Wakil Laksamana Ray Griggs, selaku wakil ketua Australian Defence Force (ADF), pada 9 Desember 2014 lalu, untuk mengadakan pembicaraan dengan Timoci Natuva, Menteri Pertahanan, Keamanan Nasional, dan Imigrasi Fiji. Kunjungan ini merupakan kunjungan perwira senior pertama Australia ke Fiji sejak 2006 (AAP 2020). Tidak hanya itu, layatan ini merupakan langkah penting untuk membangun kembali hubungan pertahanan substantif antara Australia dan Fiji, dan akan membentuk dasar kemitraan baru antara ADF dan RFMF. Dalam satu kesempatan, Laksamana Griggs juga berkomentar bahwa banyak yang akan dicapai oleh dua militer tersebut, termasuk di bidang keamanan maritim, penjaga perdamaian, teknik dan bantuan kemanusiaan dan bantuan bencana (Australia Government Department of Defence 2014).

Memasuki tahun 2017, satu kapal patroli Angkatan Laut Australia, HMAS Wollongong, telah melaksanakan kunjungan resmi ke Fiji, termasuk latihan empat hari di Zona Ekonomi Eksklusif Fiji dengan Kapal Angkatan Laut Republik Fiji, Kula. Selain itu, Australia bekerja sama dengan Fiji untuk melakukan perbaikan sebesar AUD \$13,5 juta terhadap dua dari tiga Kapal Patroli Pasifik Australia menjelang penyediaan dua kapal penggantinya yang akan dibuat di Australia di bawah Program Keamanan Maritim Pasifik (Australia Government Department of Defence 2017). Fiji dan Australia juga bekerja sama dalam pembangunan kembali Blackrock Camp pada tahun 2019 di Nadi dan bersama-sama mendesain ulang Pusat Layanan Esensi Maritim Fiji yang baru-menggabungkan Markas Besar Angkatan Laut Republik Fiji, Pusat Koordinasi Pengawasan dan Penyelamatan Maritim Fiji , Radio Pesisir dan Layanan Hidrografi Angkatan Laut Fiji. Menurut Hon Alex Hawke MP, sebagai Asisten Menteri Pertahanan, Australia Blackrock Camp adalah kunci kemajuan militer Fiji.

"Proyek pembangunan kembali Blackrock Camp adalah kunci bagi kemajuan kualitas pasukan keamanan dan militer Fiji ketika mereka bersiap untuk tugas kepolisian, latihan penjaga perdamaian dan penyebaran perdamaian secara internasional," (Australia Government Departement of Defence 2019). 
Intensifikasi kerja samakerja sama Fiji dan Australia dalam bidang keamanan yang terakhir dapat terlihat dari pembuatan Kemitraan Vuvale Fiji-Australia yang dibangun pada September 2019 lalu. Kemitraan Vuvale Fiji-Australia merupakan sebuah perjanjian antara Australia dan Fiji yang terdiri dalam berbagai bidang, salah satunya dalam hal keamanan dan penjagaan perdamaian. Perjanjian tersebut mengikat Australia dan Fiji untuk masuk ke dalam kemitraan pemeliharaan perdamaian dan untuk mendukung "Gabungan Pasukan Pertahanan Australia - Republik Pasukan Militer Fiji” pada misi penjaga perdamaian, kegiatan pelatihan lebih lanjut dan kerja sama intelijen. Hal tersebut dibangun di atas penandatanganan nota kesepahaman antara Fiji dan Australia pada April 2019 untuk mengembangkan Blackrock Camp sebagai pusat regional untuk pelatihan polisi dan penjaga perdamaian (Department of Foreign Affairs and Trade 2019).

\section{Kolaborasi Australia-Fiji dalam Penjagaan Perdamaian dan Keamanan Internasional}

Selain dalam bidang kerja sama bilateral dan keamanan regional, hubungan Australia-Fiji terlihat semakin erat dalam konteks internasional yang lebih luas. Hal ini dapat ditilik dari semakin rekatnya kerja sama antar kedua negara tersebut dalam kegiatan peacekeeping. Pada Oktober 2019 lalu, Perdana Menteri Australia Scott Morrison membuat pengumuman bahwa pasukan penjaga perdamaian Australia akan bergabung dengan pasukan penjaga perdamaian Fiji dalam penempatan bersama di Dataran Tinggi Golan, Suriah, sebagai bagian dari Pasukan Pengamat Pengunduran Diri PBB (UNDOF) (Clarke 2019). Pasukan ad hoc yang dibentuk oleh PBB ini telah didirikan di Dataran Tinggi Golan telah ada sejak 1974 untuk memantau dan mengawasi perjanjian gencatan senjata antara pasukan Israel dan Suriah `. Hingga saat ini, pasukan Fiji dan Australia termasuk kontributor terbesar dalam misi tersebut (United Nations Peacekeeping 2020)

Tidak hanya di Suriah, Australia saat ini memiliki sejumlah kontingen ADF yang dikerahkan ke tiga misi penjaga perdamaian PBB lainnya - Misi PBB di Sudan Selatan (UNMISS), Organisasi Pengawasan Gencatan Senjata PBB (UNTSO) dan Pasukan Pemelihara Perdamaian PBB di Siprus (UNFICYP). Dalam konteks keamanan internasional di Timur Tengah, Australia memiliki pengamat militer yang ditempatkan di United Nations Truce Supervision Organization (UNTSO) sejak 1956 dan saat ini memiliki 12 personel ADF yang dikerahkan untuk misi tersebut. UNTSO juga secara teratur menyediakan personel untuk mendukung Observer Group 
Golan di United Nations Disengagement Observer Force (UNDOF). Selain operasi penjaga perdamaian $\mathrm{PBB}$, Australia juga terus mempertahankan pengerahan kontingen ke Pasukan Multinasional \& Pengamat di Sinai (MFO) (McDougall 2017).

Fiji, di sisi lain, telah menyumbangkan personil untuk pemeliharaan perdamaian PBB sejak 1978 (Qarase 2004). Saat ini memiliki personil militer dan polisi dikerahkan untuk operasi penjaga perdamaian $\mathrm{PBB}$ di Timur Tengah (termasuk Irak, Libanon, Yaman dan Golan), serta Sudan Selatan dan Darfur. Fiji juga telah menunjukkan kesediaan untuk tetap ditempatkan di misi PBB yang menghadapi risiko keamanan yang signifikan. Misalnya, pada tahun 2014 lebih dari 44 penjaga perdamaian Fiji diculik di Golan oleh aliansi Al-Qaeda. 44 warga Fiji tersebut berpartisipasi dalam Pasukan Pengamat Pengunduran Diri PBB (Charbonneau \& Ohayon 2014). Kerja sama dan membaiknya hubungan antara Australia dengan Fiji dalam hal ini merupakan sebuah perkembangan baru dan menandai adanya dinamika baru dalam kerja sama pertahanan yang kuat.

Peacekeeping Co-deployment yang dilakukan Australia bersama Fiji memunculkan potensi penguatan dalam hubungan bilateral di antara keduanya. Hal tersebut berimplikasi terhadap komitmen gabungan antara kedua negara terhadap multilateralisme internasional yang lebih luas. Australia juga ingin memastikan bahwa Fiji berada dalam posisi untuk mempertahankan komitmennya terhadap pemeliharaan perdamaian PBB. Dengan turut menjadikan pemeliharaan perdamaian sebagai salah satu pusat kebijakan luar negeri, pemerintah Fiji secara tidak langsung telah meningkatkan kemampuan militer untuk campur tangan dalam politik dalam negeri. Hal ini dapat dilihat dari bagaimana Australia memberikan Fiji Bushmasters-kendaraan angkutan personil infanteri buatan Australia-dan memberikan angkutan udara strategis kepada RFMF untuk mendukung penyebaran pasukan perdamaian Fiji ke pusat komando MFO di Sinai (Wyeth 2019). Fiji akan menggunakan kendaraan tersebut untuk membentuk perlindungan pasukan yang melindungi Pengamat PBB di Dataran Tinggi Golan dan Suriah, yang mencakup personil Angkatan Pertahanan Australia.

Pada akhirnya, keterlibatan pertahanan Australia dengan Fiji juga mendukung peningkatan pengaruh Pemerintah Morrison. Maka dari itu, Australia menjadi lebih semakin berkonsentrasi terhadap perekatan relasi dengan Fiji untuk mengurangi pengaruh dari negara-negara seperti Tiongkok dan Rusia. Rusia sebelumnya telah terlibat dengan Fiji untuk mendukung penyebaran pasukan penjaga perdamaiannya, termasuk menyediakan peralatan untuk 
mendukung penempatan pasukannya di Dataran Tinggi Golan. Tiongkok juga telah terlibat dengan Fiji untuk mendukung upaya pemeliharaan perdamaian dengan penyediaan dana dan pemberian pelatihan militer terhadap personil RFMF . Dengan kata lain, keputusan Australia untuk bekerja sama dengan Fiji memiliki dimensi dan sangkut-paut dengan dinamika geopolitik yang terjadi di kawasan tersebut (Brown 2012). Lantas, karena adanya intensifikasi hubungan ini, Australia dan Fiji dapat memiliki kesamaan untuk mengatasi common security dan ingin meningkatkan peluang bersama dalam mencapai kesejahteraan yang lebih baik baik di dalam negara masing-masing, regional, maupun internasional.

\section{Menelusuri Perubahan Sikap Australia dan Fiji dalam Bidang Keamanan Pasca-kudeta tahun 2006}

Kerekatan hubungan antara Australia dan Fiji dapat ditarik mundur semenjak Pemerintah Australia menanggapi Kudeta Fiji pada 2006 lalu. Australia memiliki kepentingan strategis untuk mewujudkan stabilitas di wilayah Pasifik. Hal ini dapat dilihat dari cara-cara yang ditempuh oleh Canberra, antara lain dengan intervensi militer langsung untuk memulihkan pemerintah terpilih, pengenaan sanksi ekonomi penuh, pemboikotan perdagangan dan agenda olahraga internasional, maupun juga pembekuan aset yang berasal dari Suva, serta pembatasan aktivitas bisnis dan pariwisata. Sebelumnya, Australia juga sempat mengambil jalur persuasif untuk membujuk pemerintah Fiji untuk mengadakan pemilihan ulang, namun Australia gagal dalam memberikan pengaruh diplomatiknya terhadap pemerintah Fiji (Hayward-Jones 2011).

Langkah-langkah koersif tersebut lantas membuat reputasi Australia

di Kawasan Pasifik Selatan dan internasional menurun. Terlebih, pada waktu yang sama Australia sedang berupaya untuk menjadi anggota tidak tetap Dewan Keamanan Perserikatan Bangsa-Bangsa (DK PBB) (Hayward-Jones 2011). Selain itu, pengucilan Australia atas Fiji telah merusak hubungan regionalnya dengan Papua Nugini, Kepulauan Solomon dan Vanuatu (Herr 2010). Vakumnya kerja sama antara Australia dengan negara-negara tersebut telah memberikan Tiongkok kesempatan untuk masuk dan membina relasi dengan negara-negara kepulauan tersebut. Mengingat pentingnya Pasifik sebagai bagian dari lingkaran konsentris Canberra, lantas telah menjadi kepentingan nasional Australia untuk merestorasi hubungan bilateralnya dengan Fiji dan turut aktif dalam menjaga keamanan di kawasan tersebut. 
Di sisi lain, dampak dari kudeta Fiji telah dirasakan oleh negara itu sendiri. Pasca pergantian rezim secara paksa tersebut, Fiji mengalami keruntuhan ekonomi yang menyebabkan ketidakstabilan di negaranya. Sebagai konsekuensi langsung dari kudeta militer, kerja sama pertahanan dan bantuan dari Australia, Selandia Baru, Prancis, dan Amerika Serikat telah berhenti. Hilangnya kerja sama pertahanan dengan mitra-mitra utama juga telah melemahkan kemampuan Fiji untuk menangani masalah kejahatan transnasional dan memberikan keamanan perbatasannya. Ketika kembali menuju demokrasi, Fiji mengkhawatirkan akan adanya ancaman eksternal yang dapat mengganggu keamanan wilayahnya. Terlebih lagi, Fiji telah dikucilkan dalam forum regional seperti Forum Kepulauan Pasifik (PIF). Demi menjaga keamanan wilayah sebagai kepentingan nasionalnya, Fiji lantas berusaha kembali terbuka dengan dunia internasional untuk pemulihan negara pasca kudeta militer yang terjadi (Tatre 2010).

Australia dan Fiji pada akhirnya memiliki tujuan yang sama untuk melindungi kepentingan nasionalnya masing-masing dan menjaga keamanan, serta stabilitas kawasan. Alasan mengapa kedua negara tersebut memutuskan untuk bekerja sama dalam bidang keamanan dapat terlihat dari beberapa faktor. Pertama, Fiji merupakan negara yang memiliki basis militer kuat-meskipun kecil dalam skala regional. RFMF merupakan garda terdepan Fiji yang memiliki kontribusi besar, seperti dalam pembangunan nasional, menjaga keamanan maritim, serta berpartisipasi dalam penjaga perdamaian internasional. Kedua, Australia telah memiliki banyak pengalaman dalam keamanan terutama dalam hal operasi penjagaan perdamaian bersama PBB (Bellamy 2012). Dalam hal ini kedua negara masingmasing mendapatkan keuntungan. Fiji dapat bantuan dari Australia berupa pemberian alat-alat militer dan bantuan dalam menjaga keamanan wilayahnya dari ancaman eksternal. Sementara itu, Australia diuntungkan karena mendapatkan bantuan dari pasukan Fiji dalam menjaga misi perdamaian di dunia maupun dalam menjaga pengaruhnya di Kawasan Pasifik. Australia dapat mengembalikan kepercayaan negara-negara lain terhadapnya karena bantuan yang diberikan menunjukkan bentuk solidaritas negara-negara Pasifik (Tatre 2010).

\section{Tantangan Hubungan Bilateral Australia dan Fiji di Masa Depan}

Hubunganbilateralyang terjalin antara Australia dan Fiji dapat dilihat sebagai perkembangan yang positif dalam ruang lingkup keamanan nasional. Akan tetapi, terdapat pula tantangan yang melekat pada 
situasi politik di Fiji kontemporer yang akan berpotensi melahirkan tantangan keamanan baru. Ketidakstabilan internal yang telah terjadi di Fiji cukup mempengaruhi operasi organisasi regional di negara tersebut, dan mengganggu perdagangan internasional yang terjadi (Lawson 2015). Tidak hanya itu, ketidakstabilan tersebut telah merusak kapasitas Fiji untuk melawan ancaman eksternalkhususnya kejahatan transnasional-yang secara langsung maupun tidak langsung mengancam tetangga Fiji yang lebih besar seperti Australia dan Selandia Baru (Brown 2012). Dengan kata lain, konflik politik internal di Fiji-meskipun telah mereda-telah menciptakan tantangan keamanan untuk kawasan Pasifik juga bagi Fiji sendiri. Mengisolasi Fiji dari kerja sama keamanan-sebagaimana yang dilakukan oleh Australia-tidak dapat dikatakan berhasil dan pada kenyataannya menimbulkan sejumlah implikasi (Lawson 2015).

Salah satu implikasi tersebut menimbulkan sebuah potensi bahwa Suva akan semakin bergerak ke arah hubungan pertahanan yang lebih dekat dengan kekuatan baru muncul yang sedang rising: Tiongkok. Infiltrasi Beijing ke Pasifik akan melemahkan pengaruh Canberra di wilayah tersebut. Hal ini sudah terjadi ketika personel RFMF semakin banyak bepergian ke Tiongkok-atau negara-negara Asia lainnya-untuk pelatihan militer dan pengawasan maritim bersama. Pemerintah Fiji juga turut berkomitmen dalam prinsip One China Policy dan akan bekerja sama dengan lebih intensif dalam sektor-sektor strategis. Belt and Road Initiative (BRI) merupakan sebuah strategi pembangunan global China yang melibatkan pengembangan infrastruktur dan investasi terhadap negara-negara Asia, Eropa, dan Afrika. Menurut Ratu Tui Cavuilati, sebagai Duta Besar Tiongkok untuk Fiji, inisiatif BRI yang dijalankan Tiongkok merupakan dimensi tambahan untuk memperkuat konektivitas antara Beijing dan mitra-mitra pembangunan Fiji lainnya. Meskipun Fiji belum secara resmi tergabung ke dalam inisiatif tersebut, namun tidak menutup kemungkinan China akan mengajak Fiji untuk ikut bergabung (Xinhua 2018).

Selama 10 tahun terakhir, fokus Australia di Kawasan Pasifik telah memperkuat tema-tema seperti pendukung demokrasi, pemerintahan yang baik, dan memungkinkan pembangunan ekonomi berkelanjutan (Brown 2012). Tetapi di samping itu, terdapat pula fokus baru terhadap negara-negara yang berpotensi gagal. Wilayah negara-negara tersebut dapat menciptakan kekosongan kekuasaan yang mana dapat menjadi ruang bagi berkembangnya teroris atau organisasi kejahatan terorganisir sehingga dapat menjadi ancaman keamanan Australia. Terlebih lagi, posisi geografis pulau-pulau Pasifik yang terletak antara Asia dan Amerika Selatan berpotensi 
menjadikan mereka tempat yang menarik untuk mentransportasikan obat-obatan terlarang, penyelundupan manusia, dan senjata terlarang. Sebagai akibatnya, tantangan yang akan dihadapi Australia dan Fiji mungkin akan bergeser dari penjagaan perdamaian menjadi keamanan terhadap kejahatan transnasional di wilayah mereka. Hubungan bilateral keduanya akan lebih mengarah untuk membentuk struktur regional daan memperkuat kerja sama. Selain itu, besarnya pengaruh Tiongkok di wilayah tersebut juga berpotensi menggoyahkan kerekatan hubungan antar kedua negara tersebut (Brown 2012).

\section{Kesimpulan}

Hubungan kerja sama bilateral antara Australia dan Fiji pada tahun 2014-2019 dalam bidang keamanan telah mengalami dinamika yang unik. Sejak kudeta militer Fiji yang terakhir, Australia banyak membantu Fiji dan melakukan kerja sama untuk menjaga perdamaian dan stabilitas di kawasan tersebut. Hubungan kerja sama tersebut dapat terlihat dari bergabungnya kedua negara dalam misi diplomatik di Dataran Tinggi Golan, diberikannnya sejumlah unit Bushmaster kepada Fiji oleh Australia untuk memperkuat militernya, pembangunan kembali Blackrock Camp, serta pembuatan Kemitraan Vuvale Australia-Fiji. Melalui analisis pola dan dinamika kebijakan luar negeri dari kedua negara tersebut, tulisan ini telah menemukan bahwa kepentingan nasional dari kedua belah pihak dinilai akan semakin tercapai apabila Australia dan Fiji bekerja sama. Di satu sisi, Australia ingin memperkuat pengaruhnya di kawasan Pasifik melalui Fiji. Di sisi yang lain, Fiji ingin mendapatkan keamanan dari negara yang lebih besar untuk melindungi negaranya dari ancaman eksternal. Namun, seiring dengan berjalannya waktu, hubungan kedua negara mengalami pergeseran karena besarnya pengaruh Tiongkok di kawasan tersebut sehingga kepentingan Australia juga semakin sulit tercapai. Kejahatan transnasional merupakan tantangan yang akan mereka hadapi di masa depan akibat dari posisi wilayah mereka yang strategis. Keduanya memiliki common security yang sama, sehingga kemungkinan kedua negara ini akan tetap menjalin hubungan kerja sama bilateral dalam bidang keamanan untuk mempertahankan wilayahnya. 


\section{Daftar Pustaka}

\section{Buku dan Bab dalam Buku}

Cramer, C., 2015. "Conclusion: Regional Security Architecture in Oceania: Quo Vadis?”, dalam Rouben Azizian \& Carleton Cramer (eds.) Regionalism, Security \& Cooperation in Oceania. Honolulu: Asia-Pacific Centre for Security Studies, pp. 161-165

Danial \& Warsiah, 2009. Metode Penulisan Karya Ilmiah. Bandung: Laboratorium Pendidikan Kewarganegaraan.

Hayward-Jones, J, 2011. Policy Overboard: Australia's Increasingly Costly Fiji Drift. Sydney: The Lowry Institute.

Herr, R., 2010. Time for a Fresh Approach, Australia and Fiji Relations Post-Abrogation. Canberra: ASPI.

Holsti, K. J., 1990. The Political Economy of Foreign Policy in Southeast Asia. London: Macmillan.

Krisna, D., 1993. Hubungan Bilateral dan Politik Internasional. Jakarta: Gramedia.

Kusumohamidjojo, B., 1987. Hubungan Internasional: Kerangka Studi Analisis. Jakarta: Bina Cipta.

Modelski, G., 1962. A Theory of Foreign Policy. New York: Center of International Studies.

Moleong, L. J., 2000. Metode Penelitian Kualitatif. Bandung: Remaja Rosdakarya.

Morgenthau, H. J., 2005. Politics Among Nations: The Struggle for Power and Peace, $7^{\text {th }}$ Edition. New York: McGraw-Hill Education.

Rosenau, J. N., 1961. International Politics and Foreign Policy. New York: The Free Press of Glencoe.

Tatre, S., 2010. "Fiji Islands Security Challenges And Defense Policy Issues", dalam S. Tatre (ed.), Asia Pacific Countries Security Outlook and Its Implications for the Defense Sector. Tokyo: The National Institute for Defense Studies, pp. 67-84. 


\section{Artikel Jurnal}

Brown, C. P., 2012. "Australian Influence in the South Pacific". Australia Defense Force Journal, 189:66-78.

Carr, Andrew, 2014. "Is Australia a Middle Power? A Systemic Impact Approach”, Australian Journal of Foreign Affairs, 68(1):70-74.

Lawson, Stephanie. 2015. "Fiji's Foreign Relations: Retrospect and Prospect". The Round Table, 104(2):1-12.

McDougall, D., 2017. Peacekeeping from Oceania: Perspectives from Australia, New Zealand and Fiji. Round Table, 106(4): 453466.

Nye, J. S., 1999. "Redefining the National Interest", Foreign Affairs,78(4).

\section{Publikasi Resmi}

Qarase, H. L., 2004. Address to the 59th Session of the United Nation General Assembly. Prime Minister of the Republic of the Fiji Islands.

\section{Surat Kabar}

McDonald, Hamish, 2008. "Careful diplomat brokered regional cooperation”, Sydney Morning Herald, 15 Agustus 2008.

\section{Artikel Daring}

AAP, 2020. "Aust, Fiji Move to Resume Defence Ties.", AAP, 1 Maret 2020 [daring]. Dalam https://www.news.com.au/national/ breaking-news/aust-fiji-move-to-resume-defence-ties/newsstory/a85dgfec41f46aa3cf74bc3c4da92bo1 (diakses 20 Juni 2020).

Australia Government Departement of Defence, 2019. "Australia and Fiji Commit to Defence Cooperation" [daring]. Dalam https://www.minister.defence.gov.au/minister/lreynolds/mediareleases/australia-and-fiji-commit-defence-cooperation (diakses 
20 Juni 2020).

, 2014. "Australia Enhances Defence Relationship with Fiji" [daring]. Dalam https://news.defence.gov.au/media/media-releases/australiaenhances-defence-relationship-fiji (diakses 20 Juni 2020).

and Fiji Navies on Exercise" [daring]. Dalam https:/ news. , 2017. "Australia defence.gov.au/media/media-releases/australia-and-fiji-naviesexercise (diakses 20 Juni 2020).

BBC, 2006. "Background to Fiji's Four Coups" [daring]. Dalam http://news.bbc.co.uk/2/hi/asia-pacific/6209486.stm (diakses 20 Juni 2020).

Bellamy, P. A., 2012. "Peacekeeping Contributor Profile: Australia" [daring]. Dalam http://www.providingforpeacekeeping. org/2014/04/03/contributor-profile-australia/ (diakses $20 \mathrm{Juni}$ 2020).

Charbonneau \& Ohayon, 2014. "U.N., Fiji Say No Word on Location of Peacekeepers Abducted in Golan Heights"[daring]. Dalam: https://www.reuters.com/article/us-syria-crisis-peacekeepersidUSKBNoGV07420140831 (diakses 20 Juni 2020).

Clarke, M., 2019,. "Australian, Fijian Troops Head to the Middle East for Joint Peacekeeping Mission" [daring]. Dalam https://www.abc.net.au/news/2019-10-12/australia-fiji-troopshead-to-the-middle-east-for-peacekeeping/11596328 (diakses 20 Juni 2020).

Department of Foreign Affairs and Trade, 2019. "Fiji-Australia Vuvale Partnership" [daring]. https://dfat.gov.au/geo/fiji/ Documents/fiji-australia-vuvale-partnership.pdf (20 Juni 2020).

Global Security, 2020. "Fiji Peacekeeping Missions" [daring]. Dalam https://www.globalsecurity.org/military/world/oceania/fiji-pko. htm (diakses 20 Juni 2020).

United Nations Peacekeeping, 2020. "UNDOF Fact Sheet" [daring], dalam https://peacekeeping.un.org/en/mission/undof (20 Juni 2020).

Wyeth, G. (2019, October 18). "Peacekeeping and the Evolving Australia-Fiji Relationship" [daring]. dalam https:// thediplomat.com/2019/10/peacekeeping-and-the-evolving- 
australia-fiji-relationship/ (20 Juni 2020).

Xinhua. (2018, February 9). "Fiji, China Enjoy Close Relations, Eye for Future Cooperation: Fijian Official" [daring]. Diambil kembali dari Xinhuanet: http://www.xinhuanet.com/ english/2018-02/09/c 136962716.htm (20 Juni 2020). 